\title{
Oral Health Related Knowledge, Practices and Opinions of Caregivers at the Biggest Care Home for People with Disability in Turkey
}

\section{Türkiye'deki En Büyük Engelli Bakım Evindeki Bakım Personelinin Ağız Sağlığına Dair Bilgi, Uygulama ve Fikirleri}

\author{
(1D Elif Ballikaya ${ }^{1}$, (1) Esra Ergin², (10 Melek Dilek Turgut ${ }^{1}$, (1) Bahar Güçiz Doğan ${ }^{3}$, (1) Meryem Uzamış Tekçiçek ${ }^{1}$ \\ ${ }^{1}$ Hacettepe University Faculty of Dentistry, Department of Pediatric Dentistry, Ankara, Turkey \\ ${ }^{2}$ Hacettepe University Faculty of Dentistry, Department of Restorative Dentistry, Ankara, Turkey \\ ${ }^{3}$ Hacettepe University Faculty of Medicine, Department of Public Health, Ankara, Turkey
}

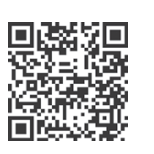

Keywords

Oral health, oral hygiene, disabled persons, caregivers

Anahtar Kelimeler

Ağız sağlığı, ağız hijyeni, engelli bireyler, bakım personeli

Received/Geliş Tarihi : 13.04 .2020

Accepted/Kabul Tarihi : 01.01.2021

doi:10.4274/meandros.galenos.2021.15870

Address for Correspondence/Yazışma Adresi: Elif Ballikaya MD,

Hacettepe University Faculty of Dentistry,

Department of Pediatric Dentistry, Ankara,

Turkey

Phone : +90 5336401499

E-mail : eyildirim@hacettepe.edu.tr

ORCID ID: orcid.org/0000-0002-1743-1881

Presented in: The research was presented at the $23^{\text {rd }}$ Congress of the European Association of Dental Public Health (EADPH) in Palma de Mallorca, October, 2018.

(C) Meandros Medical and Dental Journal, Published by Galenos Publishing House.

This is article distributed under the terms of the Creative Commons Attribution NonCommercial 4.0

International Licence (CC BY-NC 4.0).

\begin{abstract}
Objective: People with disability have worse oral health than the healthy ones usually because of their inability to perform good daily oral hygiene, lack of knowledge of their caregivers and inadequate health policies. This study aimed to evaluate the oral health-related knowledge, practices and opinions of a group of caregivers in the biggest care home in Turkey.

Materials and Methods: A total of 170 caregivers were requested to complete a questionnaire prior to receiving training regarding oral health. The chi-square test was used to evaluate the statistical significance.

Results: Among the 322 residents with disability, 255 (79.2\%) had mental disability and 64 (19.9\%) had physical disability. Of the caregivers, 147 volunteered to participate (response rate $86.5 \%$ ). Their mean age was 41.4 years. More than half of the caregivers $(n=98,66.6 \%)$ had been working for 5 to 14 years. Most of them (81.6\%) reported that they performed oral hygiene procedures for 228 residents, and $97(44.1 \%)$ reported that they brushed the teeth of residents three times per day. However, 102 caregivers reported that they did not know about the significance of dental plaque. Nearly two-thirds of the caregivers $(n=95,64.6 \%)$ had not previously received any education regarding oral care and 98 declared that they need training, of whom 74 requested that it should be practical. Female caregivers needed oral care training more than male caregivers. Although not statistically significant, caregivers who have been working for $\leq 5$ years and those with at least a high school education reported more need for oral care training. The caregivers working $\leq 5$ years had the least level of previous education on oral care. Conclusion: The caregivers need comprehensive training on oral health in the biggest care home in Turkey to be able to provide adequate oral health care for the disabled residents.
\end{abstract}

Öz

Amaç: Engelli bireyler, genellikle günlük ağız bakımlarını iyi yapamamaları, bakımlarından sorumlu kişilerin bilgi eksikliği ve yetersiz sağlık politikaları nedeniyle sağlıklı bireylere göre daha kötü ağız sağlığına sahiptir. Bu çalışma, Türkiye'deki en büyük bakım evinde bir grup bakım personelinin ağız sağlığı ile ilgili bilgi, uygulama ve görüşlerini değerlendirmeyi amaçlamaktadır. 
Gereç ve Yöntemler: Yüz yetmiş bakım personelinden, ağız sağıı̆ı konusunda eğitim verilmeden önce bir anket doldurmaları istenmiştir. İstatistiksel anlamlılı̆ı değerlendirmek için ki-kare testi kullanılmıştır.

Bulgular: Üç yüz yirmi iki engelli birey arasında, 255'i $(\% 79,2)$ zihinsel engelli ve 64'ü $(\% 19,9)$ fiziksel engellidir. Yüz kırk yedi bakım personeli çalışmaya katılmak için gönüllü olmuştur (yanıt oranı \%86,5) ve ortalama yaşları 41,4 yıldır. Bakım personelinin yarısından fazlası, ( $(n=98, \% 66,6) 5-14$ yıldır engelli bireyler için çalışmaktadır. Çoğunluğu $(\% 81,6) 228$ engelli bireyin ağız bakım uygulamalarını yaptığını ve 97'si $(\% 44,1)$ engelli bireylerin dişlerini günde üç kez fırçaladıklarını bildirmiştir. Bununla birlikte, 102 bakım personeli dental plağın önemini bilmediklerini belirtmiştir. Bakım verenlerin yaklaşık üçte ikisi $(n=95, \% 64,6)$ daha önce ağız bakımı konusunda herhangi bir eğitim almadığını ve 98'i eğitime intiyaç duyduklarını, eğitim isteyenlerin 74'ü ise eğitimin uygulamalı olması gerektiğini bildirmiştir. Kadın bakım personeli erkeklere göre daha fazla ağız bakımı eğitimine ihtiyaç duymuşlardır. İstatistiksel olarak anlamlı olmasa da 5 yıldan daha az süredir çalışan bakııılar ve en az lise mezunu olan bakıcılar ağız bakım eğitimine intiyaç duyduklarını daha fazla belirtmiş̧lerdir. Beş yıldan az çalışan bakıcılar ağız bakımı üzerine en az eğitim almış olanlardır.

Sonuç: Türkiye'deki en büyük bakım evinde bakım personelinin, engelli bireylere yeterli ağız sağlığı bakımı sağlayabilmeleri için, ağız sağıı̆̆ı konusunda kapsamlı eğitim intiyaçlarının olduğu görülmektedir.

\section{Introduction}

People with disabilities have poorer oral health than their counterparts. Especially person with disabilities living in care homes have higher general and oral healthcare needs than those living in their homes. Unfortunately, their oral health is generally neglected as they commonly face challenges for getting access to dental healthcare $(1,2)$.

The inability of maintaining activities related to oral health by themselves results in a need for long term care, treatment and rehabilitation for the disabled people (3). Therefore, knowledge and motivation of the caregivers/parents about oral health as well as adequate health policies are important $(2,4)$.

According to the data of a nationwide survey conducted on 2002, there were 9 million disabled people (12.3\% of the total population) living in Turkey (5). Parallelly, there has been a dramatically rise for the requirement of oral health services for the disabled people. However, the willingness of the dentists to manage a disabled person is low. This situation might be sourced from the necessity of too much time to perform dental procedures, life-threatening medical emergency possibility, limited mouth opening, requirement of hospitalization and lack of specialized dentists (6). Therefore, training of the caregivers/ parents regarding primary preventive measures including proper nutrition, tooth brushing, flossing, fluoride applications to improve oral health status and minimize dental treatment needs is necessary. However, caregivers are frequently unaware of the importance of oral health and lack of the appropriate knowledge and skills to perform oral health care $(7,8)$.

In Turkey, there have been recent reports regarding the oral health status of older people or people with specific disability living in care homes $(9,10)$. On the other hand, there has been no report concerning caregivers, based on our literature search. From this point, the aim of this study was to evaluate the oral health related knowledge, practices and opinions of a group of caregivers in the biggest care home for the disabled in Turkey.

\section{Materials and Methods}

This descriptive study was approved by the Ministry of Family and Social Policy in Turkey (20240283202.99-E.58558/2017). It was conducted at the biggest care home in Ankara, Turkey, between September and December 2017 (11). The care home was considered as the biggest depending on acreage, numbers of homes, person capacity as stated in the website of the Ministry of Family and Social Policy (11).

In the care home, a total of 700 caregivers in charge of 670 disabled people have been working with three shifts. Among them, 170 caregivers working between 08:00 am-16:00 pm, and belonging to the second shift period, were invited to participate in the study and requested to complete a structured, a face-to-face questionnaire. Out of the 170 caregivers, 147 of them who looked after 332 disabled people, volunteered to take part in the study (response rate $86.5 \%$ ).

The variables in the questionnaire included oral care practices of the disabled people; knowledge of the caregivers about dental plaque, oral health; attitude to oral care of the disabled people. For pretesting regarding the content and intelligibility, the first draft of the questionnaire was implemented on 15 caregivers in different age groups in the institution. Due to the feedbacks of the caregivers, some related open-ended questions were restructured. 
Among the three questions related on oral health knowledge, the first one was about the frequency of dental visits for the disabled people. The correct answer was accepted as every three months since the disabled people need special health care with low health literacy level (12). The second question was about dental plaque and the answer defining the dental plaque as food accumulations on the teeth was accepted as correct. In the third question it was asked whether the oral health effects the general health. The correct answer was "yes" as World Health Organization defines the oral health as an integral part of the general health (13). The percentage of the caregivers who answered the three questions correctly was calculated.

\section{Statistical Analysis}

After completing of the questionnaires, the obtained data were analyzed statistically by using SPSS for Windows 21.0 (IBM Corp. Released 2012. Armonk, NY: IBM Corp.). Number and percentages were estimated for descriptive statistics. Chi-square and Fisher Exact test were used to assess the significance of the differences between categorical variables. The significance level was considered as 0.05 in all analyses.

\section{Results}

The mean age of the caregivers was $41.4 \pm 7.4$ years (minumum-maximum: 23-58). Two-thirds (66.7\%) were female. Only 11 (7.5\%) had received university education and 57 (38.8\%) had graduated primary school.

Regarding the disabled residents whom the caregivers given care, almost half of them (45.3\%) were between 19-34 years of age; 255 (79.2\%) were mentally disabled and 64 (19.9\%) had physical disability (Table 1).

Of the caregivers, 120 (81.6\%) reported that they performed oral hygiene procedures for 228 residents $(70.8 \%$ of 322$)$ but brushing frequency of the 8 residents had not been recorded. The caregivers reported that they brushed the teeth of 97 residents (44.1\%) three times a day, among the remaining 220 residents.

Among the caregivers, $61.0 \%$ talked that they did not feel anything while performing oral care of the disabled residents, while $21.6 \%$ did not like oral hygiene procedures. The reasons of feeling uncomfortable were "having nausea during the procedures", "not accepting the procedure as part of their profession" and "not having enough time". Only 6 caregivers $(5.0 \%)$ stated that they felt better while performing oral care of the disabled people.

The answers also revealed that time concerns as well as uncooperative behaviors of the disabled residents were the most common reasons for not dealing with the oral care of the residents. Some of the caregivers suggested that there was a need for a dental stuff in that care home.

Regarding the questions related to the knowledge of the caregivers about oral health, 102 (69.4\%)

\begin{tabular}{|l|l|l|}
\hline \multicolumn{2}{|l|}{ Table 1. The distribution of disabled people by age and disability type (Ankara-Turkey, 2017) } \\
\hline Age groups and disability type (n=322) & $\mathbf{n}$ & \% \\
\hline Age groups & 5 & 1.6 \\
\hline$\leq 5$ & 18 & 5.6 \\
\hline $\mathbf{6 - 1 1}$ & 25 & 7.8 \\
\hline $\mathbf{1 2 - 1 8}$ & 146 & 45.3 \\
\hline $\mathbf{1 9 - 3 4}$ & 124 & 38.5 \\
\hline $\mathbf{3 5 - 6 4}$ & 4 & 1.2 \\
\hline $\mathbf{6 5}$ & \multicolumn{2}{|l|}{} \\
\hline Disability type* & 255 & 79.2 \\
\hline Mental & 64 & 19.9 \\
\hline Physical & 24 & 16.3 \\
\hline Psychiatric & 7 & 2.2 \\
\hline Neurological & 7 & \\
\hline *More than one disability; the percentages calculated from total disabled people & \\
\hline
\end{tabular}


reported that they had no idea about dental plaque and only 9 (12.9\%) suggested that the frequency of dental visits should be once in three months. Ninetyfour-point six percent of the caregivers stated that general health was related to oral health. Only 6 caregivers answered all the three questions correctly. Although the questions on dental plaque and frequency of dental visits for the disabled people were answered correctly more by females than males, the difference was not statistically significant (Table 2). The caregivers with at least a high school education, defined the dental plaque correctly more than those of the caregivers with primary school and elementary school education $(p<0.000)$. However, the question asking the frequency of dental visit for the disabled people was answered less correctly by the caregivers with at least a high school education but there was no statistically significant difference $(p>0.05)$.
More than half of the caregivers (54.4\%) did not agree providing oral care of the uncooperative disabled residents by force. However, it was learned that at the care home, most of the disabled people being referred to a dentist only when needed.

The duration of working as a caregiver (in years) was also questioned. More than half of the caregivers ( $n=98,66.6 \%$ ) had been working for 5 to 14 years. Although statistically insignificant, a correlation of increase in the duration of working and decrease in the number of correct answers of the questions regarding the dental plaque and the frequency of dental visit was detected.

Of the caregivers, $46.3 \%$ asserted that they knew how to provide oral care. However, nearly two-thirds ( $n=95,64.6 \%$ ) had no previous training on oral care of disabled. On the other hand, 98 (66.7\%) declared that they need training, and the most preferred method was practical training. According to their reports, it was

\begin{tabular}{|c|c|c|c|c|c|c|c|c|c|c|c|c|}
\hline \multirow[b]{3}{*}{ Characteristics } & \multicolumn{5}{|c|}{ Dental plaque } & \multirow{3}{*}{$p$} & \multicolumn{5}{|c|}{ Frequency of dental visit for disabled } & \multirow{3}{*}{$p$} \\
\hline & \multicolumn{2}{|c|}{ Known } & \multicolumn{2}{|c|}{ Not known } & \multirow{2}{*}{$\begin{array}{l}\text { Total } \\
\mathbf{n}\end{array}$} & & \multicolumn{2}{|c|}{ Known } & \multicolumn{2}{|c|}{ Not known } & \multirow{2}{*}{$\begin{array}{l}\text { Total } \\
\mathbf{n}\end{array}$} & \\
\hline & $\mathbf{n}$ & $\% *$ & $\mathbf{n}$ & $\% *$ & & & $n$ & $\% *$ & $\mathbf{n}$ & $\% *$ & & \\
\hline \multicolumn{13}{|l|}{ Sex } \\
\hline Male & 11 & 22.4 & 38 & 77.6 & 49 & \multirow{2}{*}{$0.129 * *$} & 6 & 12.2 & 43 & 87.8 & 49 & \multirow{2}{*}{$0.543^{* *}$} \\
\hline Female & 34 & 34.7 & 64 & 65.3 & 98 & & 13 & 13.3 & 85 & 86.7 & 98 & \\
\hline \multicolumn{13}{|l|}{ Age group } \\
\hline$\leq 29$ & 5 & 45.6 & 6 & 54.5 & 11 & \multirow{4}{*}{$0.127 * *$} & - & - & 11 & 100.0 & 10 & \multirow{4}{*}{$0.567 * * *$} \\
\hline $30-39$ & 17 & 39.5 & 26 & 60.5 & 43 & & 7 & 16.3 & 36 & 83.7 & 43 & \\
\hline $40-49$ & 20 & 26.7 & 55 & 73.3 & 75 & & 9 & 12.0 & 66 & 88.0 & 70 & \\
\hline$\geq 50$ & 3 & 16.7 & 15 & 83.3 & 18 & & 3 & 16.7 & 15 & 83.3 & 18 & \\
\hline \multicolumn{13}{|l|}{ Level of education } \\
\hline Primary school & 6 & 10.5 & 51 & 89.5 & 56 & \multirow{3}{*}{$<0.001^{* *}$} & 11 & 20.8 & 46 & 79.2 & 57 & \multirow{3}{*}{$0.082^{* *}$} \\
\hline Secondary school & 12 & 35.3 & 22 & 64.7 & 44 & & 5 & 14.7 & 29 & 85.3 & 34 & \\
\hline 2High school & 27 & 48.3 & 29 & 51.8 & 56 & & 3 & 5.4 & 53 & 94.6 & 56 & \\
\hline \multicolumn{13}{|c|}{ Duration of working as caregiver (years) } \\
\hline$\leq 5$ & 15 & 37.5 & 25 & 62.5 & 40 & \multirow{4}{*}{$0.708 * *$} & 6 & 15.0 & 34 & 85.0 & 40 & \multirow{4}{*}{$0.682 * *$} \\
\hline $5-9$ & 15 & 28.8 & 37 & 71.2 & 52 & & 7 & 13.5 & 45 & 86.5 & 48 & \\
\hline $10-14$ & 13 & 28.3 & 33 & 71.7 & 46 & & 6 & 13.0 & 40 & 87.0 & 45 & \\
\hline$\geq 15$ & 2 & 22.2 & 7 & 77.8 & 9 & & - & - & 9 & 100.0 & 8 & \\
\hline
\end{tabular}


found that females need oral care education (75.5\%) more than males $(55.1 \%),(p=0.035)$. Although not statistically significant, the caregivers who have been working for less than five years and those with at least a high school education, reported more need for oral care training. The caregivers who have been working for a time between ten to fourteen years were found to be more educated on oral care previously $(p=0.013)$. Many of the caregivers with a duration of working less than 5 years $(75.0 \%)$ reported that they needed oral care education (Table 3 ).

\section{Discussion}

Oral health is undoubtedly accepted as part of the general health (13). One of the common problems effecting oral health is dental caries. Although it is assumed to be preventable, dental caries still remains to be a great public health problem especially in underdeveloped and developing countries (14).

Primary preventive applications are necessary in order to decrease caries prevalence. The first step should be the timely delivery of educational information to populations at high risk for developing caries. Educational programs for both the parents and caregivers are important to promote good oral health (2). Especially, the parents/caregivers of people belonging to high-risk groups should be targeted. Within this respect, the caregivers working in care homes should not be neglected. This group may involve very high numbers in countries with high disabled people populations. In the biggest rehabilitation center in Ankara where the current study held, 670 disabled people were living and 700 caregivers were responsible from them. Since the data collection of this study was performed between 9:00-16:00, only 170 caregivers were reached because of their shifted working system and 147 of them accepted to participate.

The area of responsibility of the caregivers at the survey care home includes nursing of the disabled individuals with regard to daily requirements such as nutrition, wearing, intake of medicines and medical consultation. Not all but $81.6 \%$ of the caregivers stated that they performed oral care of the disabled people. The rest of the caregivers did not deal with oral care because of the uncooperative behaviors of the disabled residents and time concerns. In parallel, Wardh et al. (15) reported that lack of time was the most asserted reason for not performing oral care of the disabled individuals. In another study, the main problem for the caregivers was to gain access to the oral cavity of the geriatric patients. They found oral health care is a low priority for the stuff (16). On the contrary, in another study, nursing staff considered oral care of the disabled individuals as a part of their role (17). Phylpo et al. (18) conducted a study on oral care needs and barriers perceived by caregivers. Physical resistance to oral care and lack of time have been regarded as barriers by the caregivers. In present study, some of the caregivers reported that they did not consider the oral care of the residents as part of their profession. Our results indicated a need for the encouragement of the caregivers to take part in the oral hygiene procedures of the disabled people. This may be accomplished by emphasizing the importance of oral hygiene in preventing caries and periodontal disease and in improving oral health. They might feel better in case the importance of their role is explained.

With regard to the feelings of the caregivers during oral care, $61.0 \%$ of them reported no change in their feelings while $21.6 \%$ did not like the procedure because of nausea or time concerns. Wardh et al. (15) compared attitude of nursing personnel working with elderly and severely disabled patients. They reported that nearly $30.0 \%$ of the respondents indicated some degree of embarrassment similar to the results of the present study. These results again emphasize the importance of encouragement of the caregivers in taking part of the oral care procedures.

More than half of the caregivers in this study reported that they did not agree in providing oral care of the uncooperative disabled people by force. In the current study, $79.2 \%$ of the residents whom the participants gave care were mentally disabled. Socially learning theory which posits that learning is influenced by psychological factors and behavioral learning theory could aid caregivers to better communicate and guide people with learning disability during oral care (19).

Diet, nutrition, oral hygiene, exposure to fluorides, tobacco and alcohol, acute and other chronic medical conditions are the six main factors included in the etiology of dental diseases (20). People with disabilities are at more risk of some of these factors (21). People at high risk for caries must visit dentist once in three months, regularly (12). In the present 
study, only $12.9 \%$ of the caregivers suggested that the frequency of dental visits should be once in three months. Most of the disabled people have being referred to dental visit only in case of a complaint. Tiller et al. (22) also reported that people living in the community care were found to access dental services less frequently and more likely to attend only when having trouble. Financial problems or lack of specialized medical center with special equipment were stated as the reasons for not attending regular visits $(16,23)$. In Turkey, the general health insurance covers the fees of dental examination, preventive procedures and most of the dental treatments. In the city where the present study was conducted, there have been enough oral health care centers and university clinics belonging to the government. Given these circumstances, the lack of regular visits is related to disregarding the importance of oral care.

In the present study, the distribution of correct knowledge on dental plaque and frequency of dental visits by sex, age groups and experience did not differ significantly. Abullais et al. (24) also evaluated 161 caregivers' knowledge, attitudes and practices on oral healthcare for the disabled and reported no difference in knowledge levels by sex and experience but reported significantly better knowledge in 20-29 years age group compared to the other age groups. They recommended that the knowledge of dental biofilm and its etiology in dental and periodontal diseases should be taught to the caregivers.

The second step of the primary prevention for the disabled people is the practical programs to promote appropriate oral hygiene procedures. Reportedly by Phylpo et al. (18), $70 \%$ and $75 \%$ of the caregivers stated to have enough/comprehensive theoretical knowledge and practical skills, respectively and $46 \%$ were relevant to getting oral health education. In this study, more than half of the caregivers reported that they did not know how to provide oral care of disabled individuals as they had not a training before. However, many of them were eager to get the oral care training. In parallel, the nursing staff in a study (15) claimed

Table 3. Previous oral care education and opinion about oral care training of the caregivers by to some characteristics (Ankara-Turkey, 2017)

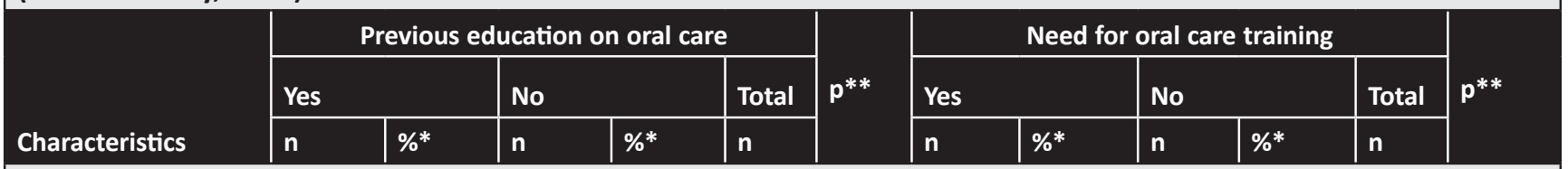

Sex

\begin{tabular}{|c|c|c|c|c|c|c|c|c|c|c|c|c|}
\hline Male & 14 & 28.6 & 35 & 71.4 & 49 & \multirow{2}{*}{0.223} & 27 & 55.1 & 22 & 44.9 & 48 & \multirow{2}{*}{0.035} \\
\hline Female & 38 & 38.8 & 60 & 61.2 & 98 & & 71 & 75.5 & 27 & 24.5 & 94 & \\
\hline
\end{tabular}

Age group

\begin{tabular}{|c|c|c|c|c|c|c|c|c|c|c|c|c|}
\hline$\leq 29$ & 3 & 27.3 & 8 & 72.7 & 11 & \multirow{4}{*}{0.770} & 8 & 72.7 & 3 & 27.3 & 9 & \multirow{4}{*}{0.868} \\
\hline $30-39$ & 15 & 34.9 & 28 & 65.1 & 43 & & 27 & 62.8 & 16 & 37.2 & 41 & \\
\hline $40-49$ & 29 & 38.7 & 46 & 61.3 & 75 & & 50 & 66.7 & 25 & 33.3 & 74 & \\
\hline$\geq 50$ & 5 & 27.8 & 13 & 72.2 & 18 & & 13 & 72.2 & 5 & 27.8 & 18 & \\
\hline
\end{tabular}

Level of education

\begin{tabular}{|c|c|c|c|c|c|c|c|c|c|c|c|c|}
\hline Primary school & 22 & 38.6 & 35 & 61.4 & 57 & \multirow{3}{*}{0.202} & 37 & 66.1 & 20 & 33.9 & 56 & \multirow{3}{*}{0.835} \\
\hline Secondary school & 15 & 44.1 & 19 & 55.9 & 34 & & 22 & 68.8 & 12 & 31.3 & 32 & \\
\hline 2High school & 15 & 26.8 & 41 & 73.2 & 56 & & 39 & 72.2 & 17 & 27.8 & 54 & \\
\hline
\end{tabular}

Duration of working as caregiver (years)

\begin{tabular}{|c|c|c|c|c|c|c|c|c|c|c|c|c|}
\hline$\leq 5$ & 10 & 25.0 & 30 & 75.0 & 40 & \multirow{4}{*}{0.013} & 30 & 75.0 & 10 & 25.0 & 39 & \multirow{4}{*}{0.378} \\
\hline $5-9$ & 14 & 26.9 & 38 & 73.1 & 52 & & 31 & 59.6 & 21 & 40.4 & 49 & \\
\hline $10-14$ & 25 & 54.3 & 21 & 45.7 & 46 & & 32 & 69.6 & 14 & 30.4 & 46 & \\
\hline$\geq 15$ & 3 & 33.3 & 6 & 66.7 & 9 & & 5 & 55.6 & 4 & 44.4 & 8 & \\
\hline
\end{tabular}


education and training in daily oral care and suggested practical help from dental personnel. Abullais et al. (24) also recommended that educational and training programs should be routinely organized by the dental professionals in oral healthcare for the caregivers. It was reported by Wang et al. (25) that such training programs are effective in promoting oral health and hygiene conditions of the disabled patients.

In the present study, theoretical information about oral care has been given to the caregivers and they have been trained practically soon after the completion of the study. Both the education and training were scheduled to be performed in regular intervals in order to reach all the caregivers, but because of the shifted working system, it was not possible to train all staff.

This study was a non-representative descriptive study of the caregivers of an institute. In the present study, the caregivers' behavior about oral care was evaluated subjectively with a questionnaire. In the second step of the research, it was planned to assess oral hygiene status of the disabled people.

Health policy and some strategies including dentists, allied health professionals, primary care providers must be arranged to obtain the optimum oral health and thereby improve quality of life the disabled people.

\section{Conclusion}

The results of the present research highlighted that it would be reasonable including dentists within the staff as the dentists play a significant role in providing preventive and interceptive dental care, training parents and caregivers of the disabled individuals to obtain optimum oral hygiene. In this way, in-service training of caregivers and conveying education to disabled people on oral hygiene and ensuring follow-up with dental examinations of disabled four times a year can be organized. Besides, some preventive approaches like fluoride applications can be performed.

The results of the present research also revealed the need of the caregivers for training on oral care. Therefore, considering the shifted working system of the caregivers, efforts should be directed on oral care training both theoretically and especially practically to the all caregivers in regular intervals. Further prospective research aimed to evaluate the effectiveness of the training is required. The significance of the oral health should be emphasized to the caregivers to provide an intrinsic motivation. For improving the oral health of the disabled people, the caregivers must consider the oral care as a part of their profession.

\section{Ethics}

Ethics Committee Approval: This descriptive study was approved by the Ministry of Family and Social Policy in Turkey (20240283-202.99-E.58558/2017). This study does not require ethics committee approval.

Informed Consent: The patient is not included in this study.

Peer-review: Externally peer-reviewed.

\section{Authorship Contributions}

Concept: M.U.T., B.G.D., M.D.T., Design: M.U.T., B.G.D., M.D.T., Supervision: M.U.T., M.D.T., E.E., Materials: E.B., M.U.T., E.E., Data Collection or Processing: E.B., E.E., Analysis or Interpretation: E.B., B.G.D., M.U.T., Literature Search: E.B., M.D.T., Critical Review: M.U.T., B.G.D., M.D.T., E.E., E.B., Writing: E.B., M.D.T.

Conflict of Interest: No conflict of interest was declared by the authors.

Financial Disclosure: The authors declared that this study received no financial support.

\section{References}

1. Glassman $\mathrm{P}$, Anderson $\mathrm{M}$, Jacobsen $\mathrm{P}$, Schonfeld $\mathrm{S}$, Weintraub J, White $A$, et al. Practical protocols for the prevention of dental disease in community settings for people with special needs: the protocols. Spec Care Dentist 2003; 23:160-4.

2. Eaton KA, Lloyd HA, Wheeler M, Sullivan J, Klass C, Allen $\mathrm{Y}$, et al. Looking after the mouth - Evaluation of a pilot for a new approach to training care home carers in Kent, Surrey and Sussex. Br Dent J 2016; 221: 31-6.

3. Desai M, Messer LB, Calache H. A study of the dental treatment needs of children with disabilities in Melbourne, Australia. Aust Dent J 2001; 46: 41-50.

4. Vanobbergen JN, De Visschere LM. Factors contributing to the variation in oral hygiene practices and facilities in long-term care institutions for the elderly. Community Dent Health 2005; 22: 260-5.

5. Turkey Statistical Institute. Turkey Disability Survey. Turkey Statistical Institute. https://turkstatweb.tuik.gov.tr/PreTablo. do?alt_id=1017 Published 2002. Accessed 5 March 2019.

6. Alaçam A, Yildirim S, Çinar Ç, Bal C, Gürbüz F. The evaluation of the approach of Turkish dentists to oral health of disabled patients: a pilot study. The British Journal of Development Disabilities 2004; 50: 47-57. 
7. Frenkel H, Harvey I, Needs K. Oral health care education and its effect on caregivers' knowledge and attitudes: a randomised controlled trial. Community Dent Oral Epidemiol 2002; 30: 91-100.

8. Adams R. Qualified nurses lack adequate knowledge related to oral health, resulting in inadequate oral care of patients on medical wards. J Adv Nurs 1996; 24: 552-60.

9. IIlhan B, Çal E, Dündar N, Güneri P, Dağhan Ş. Oral health-related quality of life among institutionalized patients after dental rehabilitation. Geriatr Gerontol Int 2015; 15: 1151-7.

10. Avcu N, Ozbek M, Kurtoglu D, Kurtoglu E, Kansu O, Kansu H. Oral findings and health status among hospitalized patients with physical disabilities, aged 60 or above. Arch Gerontol Geriatr 2005; 41: 69-79.

11. Sarayengelsizyasam. https://www.sarayengelsizyasam.gov.tr/ kurum-tarihcesi. Accessed 21 December, 2020.

12. American Academy of Pediatric Dentistry. Caries-risk Assessment and Management for Infants, Children, and Adolescents. The Reference Manual of Pediatric Dentistry. Chicago, III. American Academy of Pediatric Dentistry 2020; 243-7.

13. Petersen PE. Priorities for research for oral health in the 21st Century-the approach of the WHO Global Oral Health Programme. Community Dent Health 2005; 22: 71-4.

14. Gokalp S, Dogan BG, Tekcicek MU, Berberoglu A, Unluer S. National survey of oral health status of children and adults in Turkey. Community Dent Health 2010; 27: 12-7.

15. Wardh I, Andersson L, Sorensen S. Staff attitudes to oral health care. A comparative study of registered nurses, nursing assistants and home care aides. Gerodontology 1997; 14: 28-32.

16. Wardh I, Hallberg LR, Berggren U, Andersson L, Sorensen S. Oral health care--a low priority in nursing. In-depth interviews with nursing staff. Scand J Caring Sci 2000; 14: 137-42.
17. Weeks JC, Fiske J. Oral care of people with disability: a qualitative exploration of the views of nursing staff. Gerodontology 1994; 11: 13-7.

18. Phlypo I, Palmers E, Janssens L, Marks L, Jacquet W, Declerck D. The perception of oral health and oral care needs, barriers and current practices as perceived by managers and caregivers in organizations for people with disabilities in Flanders, Belgium. Clin Oral Investig 2020; 24: 2061-70.

19. Chadwick D, Chapman M, Davies G. Factors affecting access to daily oral and dental care among adults with intellectual disabilities. J Appl Res Intellect 2018; 31: 379-94.

20. Ramos-Gomez F, Crystal YO, Ng MW, Tinanoff N, Featherstone JD. Caries risk assessment, prevention, and management in pediatric dental care. Gen Dent 2010; 58: 505-17.

21. Leake J, Birch S. Public policy and the market for dental services. Community Dent Oral Epidemiol 2008; 36: 287-95.

22. Tiller S, Wilson K, Gallagher J. Oral health status and dental service use of adults with learning disabilities living in residential institutions and in the community. Community Dent Health 2001; 18: 167-71.

23. Jeng $\mathrm{WL}$, Wang TM, Cher TL, Lin CP, Jeng JH. Strategies for oral health care for people with disabilities in Taiwan. J Dent Sci 2009; 4: 165-72.

24. Abullais SS, Al-Shahrani FMF, Al-Gafel KMS, Saeed AA, AlMathami SA, Bhavikatti SK, et al. The Knowledge, Attitude and Practices of the Caregivers about Oral Health Care, at Centers for Intellectually Disabled, in Southern Region of Saudi Arabia. Healthcare (Basel) 2020; 8: 416.

25. Wang T-F, Huang C-M, Chou C, Yu S. Effect of oral health education programs for caregivers on oral hygiene of the elderly: A systemic review and meta-analysis. Int J Nurs Stud 2015; 52: 1090-6. 